\title{
Repair, Recycle or Re-use? Creating Mnemonic Devices Through the Modification of Object Biographies During the Late Bronze Age in Switzerland
}

\author{
Benjamin Jennings
}

The biographical approach has been applied to many studies of European prehistoric metalworking which frequently discuss the potential for recycling metalwork through melting to create new objects, drawing influence from the many 'founders hoards' known from across Europe. An agglomerate of half-molten bronze objects from Switzerland suggests that such recycling practices occurred there, although previous archaeometallurgical analysis has indicated that such practices were temporally limited. This article focuses on an alternative form of recycling - the direct conversion of one object into another through cutting and reshaping - observed on several razors from Late Bronze Age (LBA) lake-dwelling contexts in Switzerland. Atypical decorative motifs on these razors identify them as having been cut from arm-or leg-ring jewellery pieces. It is suggested that these 'ring-razors' were valued as individualized objects and created as personal mnemonic devices.

The many thousands of known metal - mainly bronze - artefacts relating to the Bronze Age in Europe have not only facilitated type-chronologies, but also led to high levels of interest in prehistoric metallurgy. This interest has mainly focused on manufacturing techniques and technology (e.g. Bradley 1988; Tylecote 1992; Young et al. 1999), while archaeometric analysis has often been applied in attempts to identify metal-ore sources and alloying techniques (e.g. Rychner \& Kläntschi 1995). In recent years the 'biographical' approach (cf. Appadurai 1986; Gosden \& Marshall 1999) has been applied to investigations of the manufacturing of metalwork objects in conjunction with their utilization and deposition (Fontijn 2002; Ottaway 2001; Ottaway \& Roberts 2008; Roberts 2009). Such biographical approaches have considered the manufacture of objects from the selection of ore through to their casting and working, before turning to the social implications of their use and deposition (Fig. 1).

The potential to recycle metalwork by melting objects and re-casting them into new ones is frequently mentioned in such biographies, although it is almost impossible to observe in the archaeological or archaeo-

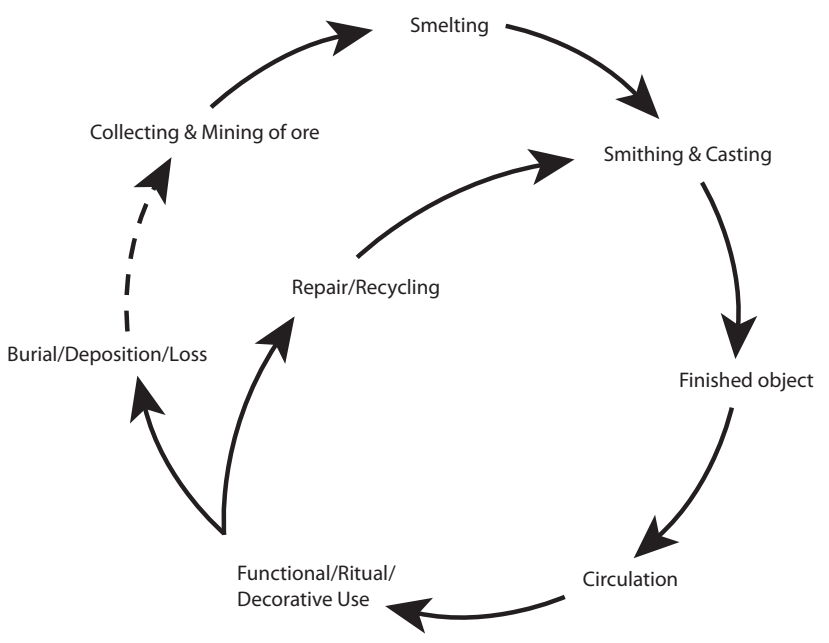

Figure 1. Biographical cycle of metalwork from production to deposition. Processes of ultimate destruction and re-incorporation of the metal elements into the environment described by Ottaway (2001) have been summarized in the dashed line. (Modified from Ottaway 2001 and Fontijn 2002.) 


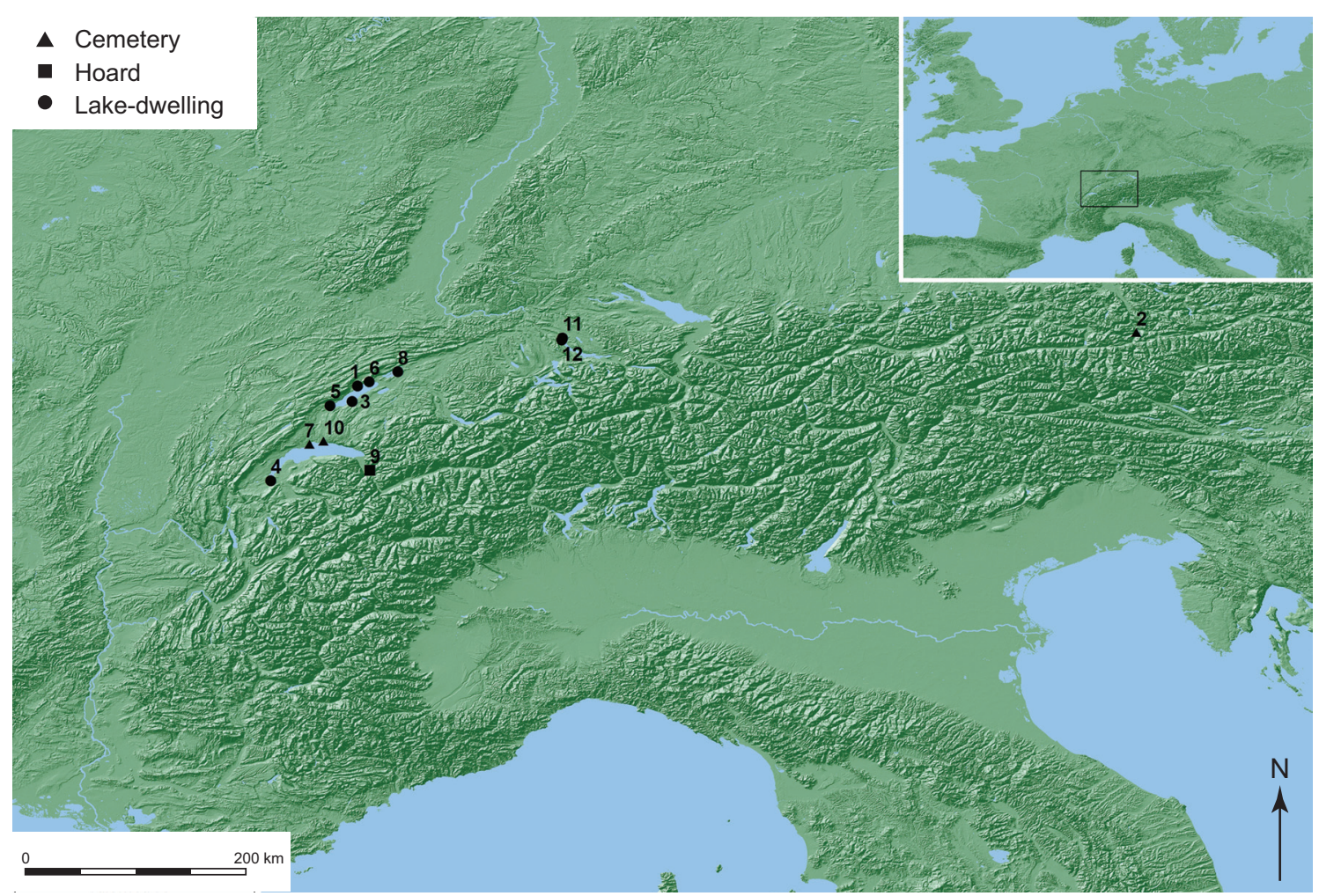

Figure 2. Main sites mentioned in the text: 1. Auvernier-Nord (Lake Neuchâtel); 2. Bischofshofen-Pestfriedhof; 3. Font - La Pianta (Lake Neuchâtel); 4. Genf-Eaux Vives (Lake Geneva); 5. Grandson-Corcelettes (Lake Neuchâtel); 6. Hauterive-Champréveyres (Lake Neuchâtel); 7. Le Boiron; 8. Mörigen (Lake Biel); 9. Ollon-Charpigny; 10. VidyChavannes; 11. Zürich-Grosser Hafner (Lake Zurich); 12. Zürich-Wollishofen Haumesser (Lake Zurich). (All maps created using the SRTM base available on the ESRI Data \& Map Pack 3.)

metric record (though see Rychner \& Kläntschi 1995). Unlike the recycling of other prehistoric material, such as pottery which may have been used as temper in other ceramics (e.g. Brück 2006, 304; Woodward 2002), the recycling - i.e. melting and recasting - of metal leaves very little (or no) trace in the archaeological and archaeometric record (although see Caple 2010). In contrast, the modification of metal items, through shaping, cutting and hammering, to create new objects is evidenced throughout Europe, and several examples of direct conversion are known from Late Bronze Age contexts in Switzerland. Such modification may also leave little evidence archaeometrically, but is more visible in the archaeological/typological record.

Despite the difficulties in observing recycled metal in the material record, an extensive archaeometric study of Late Bronze Age (LBA) metalwork from Switzerland and substantial catalogues of artefact groups from the region make this area an excellent case study for the re-use and/or recycling of materials and objects from certain sites can provide interesting insights (Fig. 2).

\section{Previous studies of Bronze Age metalwork from Switzerland}

In an isotopic and chemical composition study of Bronze Age metalwork material culture from Switzerland, Rychner and Kläntschi (1995) analysed over 900 objects. The artefacts, primarily axes, knives and sickles (combined 82 per cent of analysed objects) have a temporal range from the Middle Bronze Age (BzB$\mathrm{BzC})$ to the end of the Late Bronze Age (HaB2/B3) (see Fig. 3) and were recovered, primarily, from lakesettlement contexts. Through trace-element analysis of copper and the quantities of included impurities, Rychner and Kläntschi (1995) were able to reach several significant conclusions regarding metallurgical practices in the region. Essentially, a new (different) copper source was utilized between BzD and HaA1, which contained higher levels of lead, nickel, silver, antimony and cobalt than previous eras. Between $\mathrm{HaA} 2$ and $\mathrm{HaB} 2 / \mathrm{B} 3$ several different copper sources may have been used, though generally different to those utilized during BzD/ HaA1 (Rychner \& Klän- 


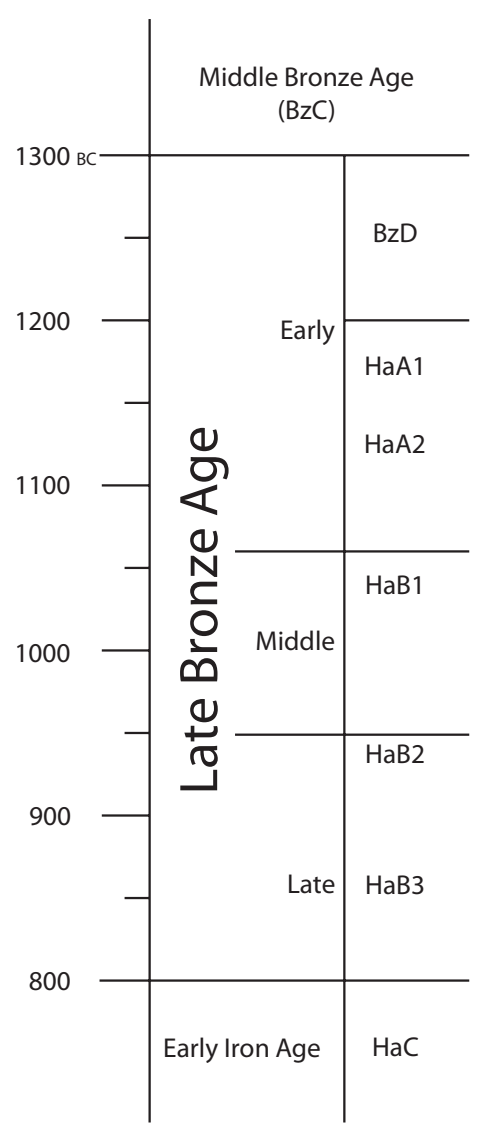

Figure 3. Chronological terminology and equivalent dates used in the northern Circum-Alpine region. (Data after Rychner 1998 and Seifert 1997).

tschi 1995, 57-61). The study of impurities included in the bronze objects permitted the observation that artefacts from each period possessed specific levels of impurities, with clearly definable and internally homogeneous alloy groups. Evidently, objects were not melted down, recycled and recast into new objects over extended periods of time, e.g. between $\mathrm{BzC}$ and $\mathrm{BzD}$ or $\mathrm{HaB} 1$ and $\mathrm{HaB} 2 / \mathrm{B} 3$, but deposited at the end of their social/use life, and new items were manufactured from new metal stock (Rychner \& Kläntschi 1995, 83).

Although several objects were identified as having been made from ancient bronze, following the remelting/re-casting process, including axes from OllonCharpingy and Geneve-Eaux Vives, they represent less than 0.5 per cent of the analysed material (Rychner \& Kläntschi 1995, 60-61). Distribution differences in impurity groups of material from eastern, central and western Switzerland provide further confirmation of the limited circulation of manufactured bronze work between these regions during the LBA, as has been noted in the distribution of typological forms and decorative designs (e.g. Rychner 1979, maps 1-14).
The widespread use of similar copper types, however, suggests that copper ingots were widely circulated for utilization in local manufacturing processes. In addition to the identification of varying metal composition over time, the study was able to identify objects with such similar impurity levels that, statistically, they could be considered to be manufactured in the same casting event or as being manufactured from the same copper ingot (Rychner \& Kläntschi 1995, 64-7). Unsurprisingly, many of these objects were found in the same location, though some were from different sites within the broad regions (east/centre/west), with a few links found between the areas indicating trade and exchange practices (Fig. 4).

Although some objects imported to the northern Circum-Alpine region have been identified through compositional analysis, for example in an early Iron Age burial at Bischofshofen-Pestfriedhof (Northover 2009), the occurrence of foreign forms of metalwork during the LBA is relatively rare in the region discussed here, and those items are usually identifiable through typological studies (e.g. 'foreign' type sickles: Primas 1986; razors: Jockenhövel 1971; bronze vessels: Sprockhoff 1966). However, two Late Bronze Age Jenišovice-Kirkendrup type cups analysed by Rychner and Kläntschi (1995, nos. 743, 744) show chemical patterns similar to that for local-type objects from Switzerland, suggesting that these cups, common in both northern Europe and the Circum-Alpine region, were manufactured locally (Patay \& Petres 1990; Thrane 1975).

\section{Distribution of ring jewellery and razors}

Extensive, and relatively up-to-date, catalogues of various Bronze Age material culture groups are available for Switzerland and the northern Circum-Alpine region. Many of the artefacts listed in these catalogues are known from 'excavations' of pile-dwellings in the latter nineteenth and early twentieth centuries, and also incorporate much of the material recovered by archaeological investigation during the second half of the twentieth century. Catalogues covering swords (Krämer 1985; Quillfeldt 1995; Schauer 1971), arm- and leg-rings (Pászthory 1985), sickles (Primas 1986), horse equipment (Hüttel 1981) and razors (Jockenhövel 1971) have been published in the Prähistorische Bronzefunde (PBF) series since the 1970s. Some significant excavations which occurred after the publication of the relevant catalogue are those of Hauterive-Champréveyres (metalwork in RychnerFaraggi 1993), and numerous excavations in advance of motorway construction, such as the A1 along the side of Lake Neuchâtel and Lake Murten (Boisaubert 




Figure 4. Distribution of objects with sufficiently similar impurities to be considered as having been manufactured in the same casting event, and objects with sufficiently similar copper elements to be considered as being manufactured from the same ingot. Objects found at the same site denoted by (i) after site name: 1. Basel-Elisabethenschanze (i); 2. Chens-sur-Léman; 3. Concise; 4. Cortaillod; 5. Estavayer-le-Lac; 6. Genf-Eaux Vives; 7. Hauterive-Champréveyres (i); 8. Kerzers (i); 9. Morges (i); 10. Mörigen; 11. Nidau; 12. Ollon-Charpigny (i); 13. Sion-Kapuzinerkloster; 14. Sugiez; 15. Sursee-Zellmoos (i); 16. Zürich-Alpenquai (i); 17. Zürich-Wollishofen. For map location see inset in Figure 2. (Data from Rychner \& Kläntschi 1995.)

et al. 2008). Two major classes of artefact not detailed under the PBF series for Switzerland are knives and spearheads. The latter have been catalogued by Tarot (2000) in a stand-alone volume, while no collated work for knives exists. Rychner (1979) has, however, created a typological chronology of knife forms for the LBA based upon numerous finds from lake-settlements.

The artefact catalogues and the archaeometric analysis of Rychner and Kläntschi (1995, see above) provide a clear indication that relatively little circulation of objects occurred between eastern and western Switzerland. The two regions appear to have utilized locally specific objects and to have been connected to different regions of Europe: eastern Switzerland to southern Germany and western Switzerland to the Rhine valley, particularly the region of Mainz and Frankfurt.

Clay and stone moulds for objects from each of these material categories, and other metalworking tools and equipment such as hammers and chisels from many lake-settlements and an anvil from ZürichWollishofen Haumesser (Heierli 1886, 13), all provide indications for metalworking and manufacture in the pile-dwellings of Switzerland. Concerning the re-use and recycling of metal, evidence is less clear. However, an 'old metal clump' from Grandson-Corcelettes, consisting of arm-/leg-rings, spearheads, winged axes and sickles in a half molten form (Wyss 1967, 12), deformed artefacts from Auvernier-Nord (Rychner 1984, 76) and partially melted ring jewellery from Font-La Pianta and Zürich-Grosser Hafner (Pászthory 1985, nos. 620, $621,1032)$ suggests that assorted objects may have been collected to meltdown and re-use (see Fig. 2 for site locations). Bronze slag waste from GrandsonCorcelettes or Yvonand provides further indication of the manufacture of objects at lake-shore settlements (Rychner 1984, 76), although no indications of the recycling of metal. 




Figure 5. Distribution of Cortaillod-type ring jewellery. For map location see inset in Figure 2. (Data from Pászthory 1985.)

The metal conglomerate from GrandsonCorcelettes contains a pair of Cortaillod-type arm-/ leg-rings and a pair of ribbed (German: gerippte) rings. The distribution of the Cortaillod-type ring jewellery is centred on the lake-dwellings of western Switzerland, in particular around Lake Neuchâtel (Fig. 5). In addition, the ribbed spearhead and sickle within this agglomerate material are similar to many others found within the northern Circum-Alpine region during the LBA. Other instances of molten ring jewellery occur at the Zürich-Grosser Hafner and Font-La Pianta lake-settlements; these are also of types that are well documented from the northern Circum-Alpine region (Pászthory 1985).

Clearly, objects were not being converted from imported objects into bronze stock, via melting, to produce locally relevant objects (cf. Fontijn 2002, 248; Roberts 2009, 13); instead, locally manufactured objects were being recycled at a low rate of consumption (seven objects from a catalogue of 2234 items: Pászthory 1985). Such conversion of 'foreign' to 'local' ('secondary local') objects may be of more relevance in northern Europe, Fontijn's region of study, where the import of metal objects was the primary method of obtaining metal. In the Alpine region, much closer to metal-ore-producing areas, such conversion may not have been required as copper and tin could have been circulated in ' $\mathrm{raw}^{\prime}$ ' ingot form, ready for manufacture into 'primary local' objects.

In addition to charting the distribution of razor types within Europe, the catalogues of Jockenhövel $(1971 ; 1980)$ demonstrate a second form of metal recycling within the northern Circum-Alpine region: direct conversion of one object into another. Based upon decorative motifs, several razors from Late Bronze Age lake-dwelling contexts were recognized as being cut from hollow arm-/legrings and hammered into the razor shape (Fig. 6). Direct conversion recycling or re-use is apparently an unusual occurrence (given the low quantity of objects known), partly because there are only certain objects that have properties sufficient for easy conversion without melting and casting. In the case of razors, this requires objects which are relatively thin but also broad enough to enable a sufficient width of blade to be achieved. Of the examples recorded by Jockenhövel (see Table 1), five display decoration identifiable as typical of 
a

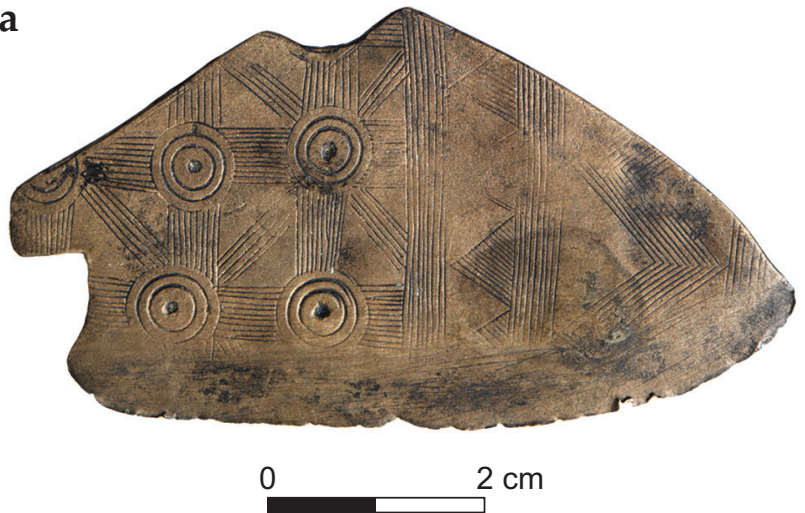

b

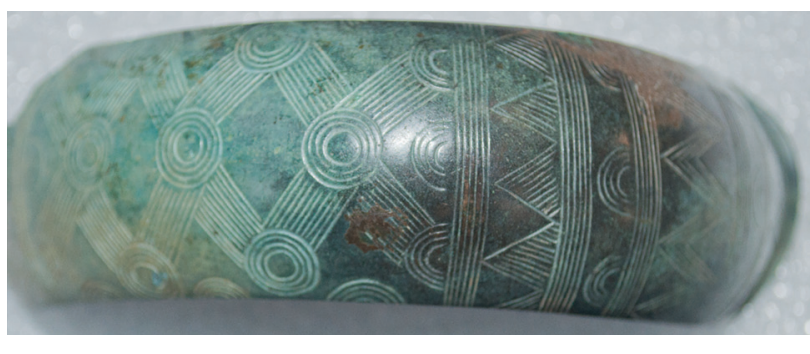

$\quad 2 \mathrm{~cm}$

Figure 6. Decoration on a) a converted ring-razor from Mörigen (Swiss National Museum, Inventory number: A-9192), and b) Corcelettes-type arm-/leg-ring from Basel-Elisabethenschanze (Historical Museum Basel no. I21431). (Photographs: a) (C) and courtesy of Swiss National Museum; and b) by the Author.)



Figure 7. Distribution of Boiron-type rings. Converted ring-razor from Auvernier marked with hollow thick-lined square. For map location see inset in Figure 2. (Data from Pászthory 1985 and Jockenhövel 1971.)

Corcelettes-type ring jewellery, while a sixth shows decoration of a Boiron-type arm-/leg-ring. These rings are common to the northern Circum-Alpine region (Figs. $7 \& 8$ ), especially western Switzerland, and the form of razor into which they were converted is found in the same area (Jockenhövel 1971). Examples of two-sided razors cut from belt buckles and dagger blades are also known from Austria, razors converted from hanging ornaments are known in France, and several examples of atypical razors cut from undecorated, un-identifiable plate work are also known from Switzerland (Jockenhövel 1971; 1980).

Other forms of direct conversion are observed elsewhere in Europe during the Bronze Age; for exam- 
Table 1. List of repaired ring jewellery, razors manufactured from other objects, and half-molten ring jewellery from Switzerland and neighbouring countries. $A T=$ Austria; $\mathrm{CH}=$ Switzerland; $F=$ France.

\begin{tabular}{|c|c|c|c|c|c|}
\hline $\begin{array}{l}\text { Site } \\
\text { no. }\end{array}$ & Object type & Site & Object variant & References & Parent object \\
\hline 1 & Molten ring jewellery & Font-La Pianta $(\mathrm{CH})$ & Estavayer-le-Lac & \begin{tabular}{|l} 
Jockenhövel 1971, 445; \\
Pászthory 1985, 620
\end{tabular} & - \\
\hline 1 & Molten ring jewellery & Font-La Pianta $(\mathrm{CH})$ & Estavayer-le-Lac & Pászthory 1985, 621 & - \\
\hline 2 & Molten ring jewellery & Zürich-Grosser Hafner $(\mathrm{CH})$ & Vinelz & Pászthory 1985,1032 & - \\
\hline 3 & Molten ring jewellery & Grandson-Corcelettes $(\mathrm{CH})$ & Corcelettes & Pászthory 1985,1420 & - \\
\hline 3 & Molten ring jewellery & Grandson-Corcelettes $(\mathrm{CH})$ & Corcelettes & Pászthory 1985,1421 & - \\
\hline 3 & Molten ring jewellery & Grandson-Corcelettes $(\mathrm{CH})$ & Ribbed & Pászthory 1985, 1676 & - \\
\hline 3 & Molten ring jewellery & Grandson-Corcelettes $(\mathrm{CH})$ & Ribbed & Pászthory 1985, 1677 & - \\
\hline 3 & Converted razor & Grandson-Corcelettes $(\mathrm{CH})$ & Tétin & $\begin{array}{l}\text { Jockenhövel 1971, 445; } \\
\text { Pászthory 1985, } 1422\end{array}$ & Corcelettes-type ring \\
\hline 4 & Converted razor & Font-La Trabatiez $(\mathrm{CH})$ & Corcelettes & Pászthory 1985, 1423 & Corcelettes-type ring \\
\hline 5 & Converted razor & Auvernier $(\mathrm{CH})$ & Auvernier & $\begin{array}{l}\text { Jockenhövel 1971, 473; } \\
\text { Pászthory 1985, } 1424\end{array}$ & Corcelettes-type ring \\
\hline 5 & Converted razor & Auvernier $(\mathrm{CH})$ & Mörigen & $\begin{array}{l}\text { Jockenhövel 1971, 426a; } \\
\text { Pászthory 1985, 1425 }\end{array}$ & Corcelettes-type ring \\
\hline 6 & Converted razor & Estavayer-Le Lac $(\mathrm{CH})$ & Atypical & $\begin{array}{l}\text { Jockenhövel 1971, 562; } \\
\text { Pászthory 1985, 1426 }\end{array}$ & Corcelettes-type ring \\
\hline 5 & Converted razor & Auvernier $(\mathrm{CH})$ & $\begin{array}{l}\text { Trapeze without } \\
\text { handle }\end{array}$ & $\begin{array}{l}\text { Jockenhövel 1971, 517; } \\
\text { Pászthory 1985, 1444 }\end{array}$ & Boiron-type ring \\
\hline 5 & Converted razor & Auvernier $(\mathrm{CH})$ & Atypical & Jockenhövel 1971, 557 & Plate work \\
\hline 7 & Converted razor & Mörigen $(\mathrm{CH})$ & Atypical & Jockenhövel 1971, 558 & Plate work \\
\hline 8 & Converted razor & Chevroux $(\mathrm{CH})$ & Atypical & Jockenhövel 1971, 559 & Plate work \\
\hline 4 & Converted razor & Font-La Trabatiez $(\mathrm{CH})$ & Atypical & Jockenhövel 1971, 560 & Plate work \\
\hline 3 & Converted razor & Grandson-Corcelettes $(\mathrm{CH})$ & Atypical & Jockenhövel 1971, 561 & Plate work \\
\hline 3 & Old material razor & Grandson-Corcelettes $(\mathrm{CH})$ & Atypical & Jockenhövel 1971, 564 & Plate work \\
\hline 7 & Old material razor & Mörigen $(\mathrm{CH})$ & Atypical & Jockenhövel 1971, 565 & Plate work \\
\hline 9 & Old material razor & Nidau-Steinberg $(\mathrm{CH})$ & Atypical & Jockenhövel 1971, 566 & Plate work \\
\hline 10 & Old material razor & Cortaillod $(\mathrm{CH})$ & Atypical & Jockenhövel 1971,566a & Plate work \\
\hline 7 & Old material razor & Mörigen $(\mathrm{CH})$ & Atypical & Jockenhövel 1971, 568 & Plate work? \\
\hline 9 & Old material razor & Nidau-Steinberg $(\mathrm{CH})$ & Atypical & Jockenhövel 1971, 569 & Plate work \\
\hline 6 & Old material razor & Estavayer-Le Lac $(\mathrm{CH})$ & Atypical & Jockenhövel 1971,569a & Plate work \\
\hline N/A & Old material razor & West Switzerland & Atypical & Jockenhövel 1971, 570 & Arm ring? \\
\hline N/A & Old material razor & West Switzerland & Atypical & Jockenhövel 1971, 571 & Plate work \\
\hline 7 & Old material razor & Mörigen $(\mathrm{CH})$ & Atypical & Jockenhövel 1971, 571a & Plate work \\
\hline 11 & Old material razor & Grünbach (AT) & Two-sided razor & Jockenhövel 1971, 363 & Dagger \\
\hline 12 & Old material razor & Grünwald (AT) & Two-sided razor & Jockenhövel 1971, 362 & Belt buckle \\
\hline 7 & Old material razor & Mörigen $(\mathrm{CH})$ & Auvernier & Jockenhövel 1971, 486 & Corcelettes-type ring \\
\hline 3 & Old material razor & Grandson-Corcelettes $(\mathrm{CH})$ & $\begin{array}{l}\text { Halfmoon without } \\
\text { handle }\end{array}$ & Jockenhövel 1971, 529 & Auvernier-type ring? \\
\hline 13 & Old material razor & Grospierres (F) & Two-sided razor & Jockenhövel 1980, 431 & Two-sided ornament \\
\hline 14 & Old material razor & Saint-Marcel/Epervans (F) & Atypical & Jockenhövel 1980, 557 & Two-sided ornament \\
\hline N/A & Old material razor & Rhone Valley (F) & Two-sided razor & Jockenhövel 1980, 240 & Ornament \\
\hline N/A & Old material razor & France & Two-sided razor & Jockenhövel 1980, 241 & Ornament \\
\hline N/A & Old material razor & France & Two-sided razor & Jockenhövel 1980, 242 & Ornament \\
\hline 3 & Repaired ring jewellery & Grandson-Corcelettes $(\mathrm{CH})$ & Corcelettes & Pászthory 1985, 1254 & - \\
\hline 3 & Repaired ring jewellery & Grandson-Corcelettes $(\mathrm{CH})$ & Corcelettes & Pászthory 1985, 1361 & - \\
\hline 3 & Repaired ring jewellery & Grandson-Corcelettes $(\mathrm{CH})$ & Mörigen & Pászthory 1985, 1623 & - \\
\hline 5 & Repaired ring jewellery & Auvernier $(\mathrm{CH})$ & Mörigen & Pászthory 1985, 1632 & - \\
\hline 15 & Repaired ring jewellery & Estavayer $(\mathrm{CH})$ & Mörigen & Pászthory 1985, 1636 & - \\
\hline N/A & Repaired ring jewellery & N/A & Mörigen & Pászthory 1985, 1641 & - \\
\hline 3 & Repaired ring jewellery & Grandson-Corcelettes $(\mathrm{CH})$ & Mörigen & Pászthory 1985,1643 & - \\
\hline 3 & Repaired ring jewellery & Grandson-Corcelettes $(\mathrm{CH})$ & Mörigen & Pászthory 1985,1668 & - \\
\hline 3 & Repaired ring jewellery & Grandson-Corcelettes $(\mathrm{CH})$ & Mörigen & Pászthory 1985, 1671 & - \\
\hline
\end{tabular}




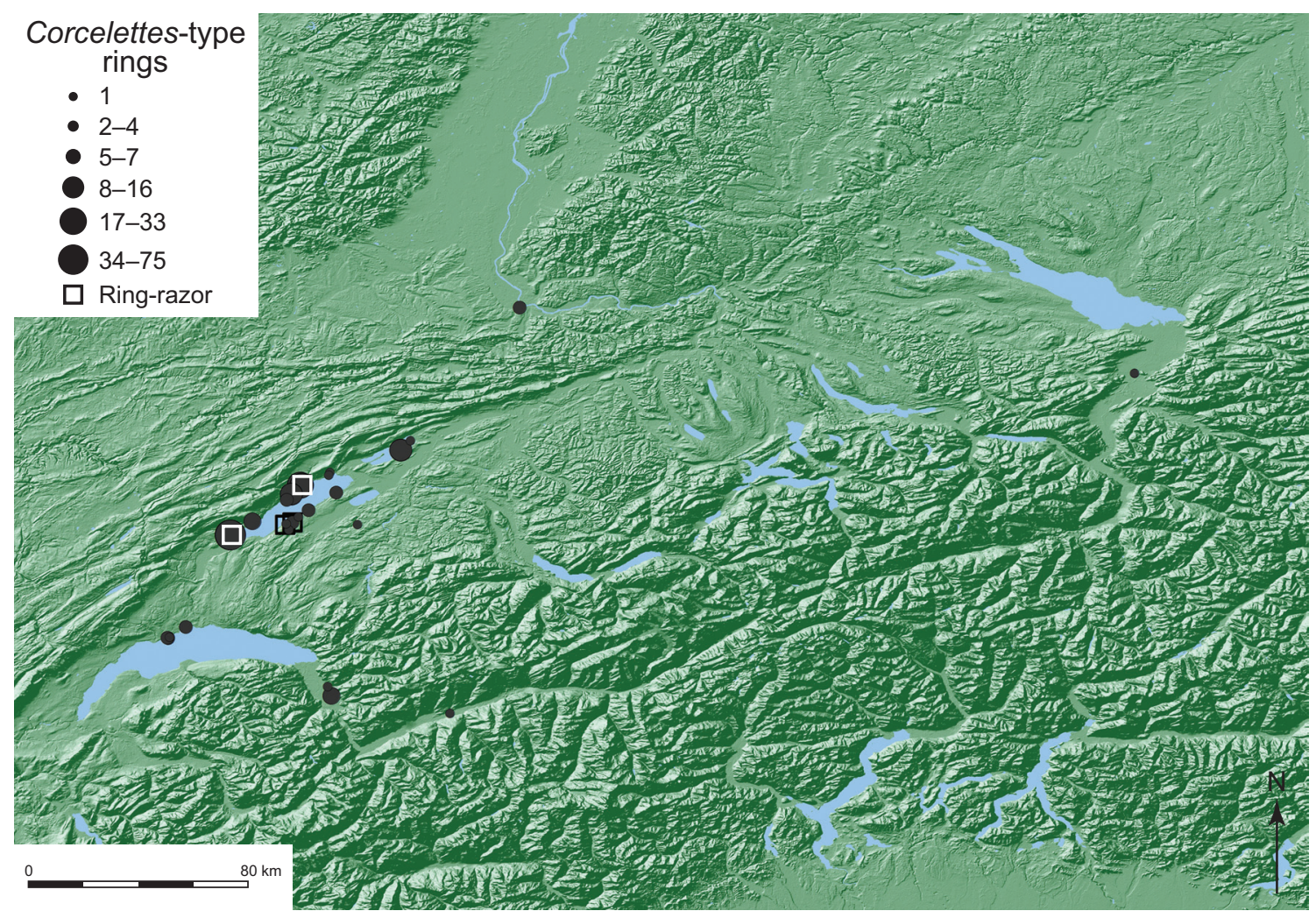

Figure 8. Distribution of Corcelettes-type rings within Switzerland. Converted ring-razors from Auvernier, Font-La Trabatiez, Grandson-Corcelettes and Estavayer-le-Lac marked with squares. For map location see inset in Figure 2. (Data from Pászthory 1985 and Jockenhövel 1971.)

ple various types of sword and rapier (e.g. Rosnoëntype) were modified for re-hafting after deliberate or accidental damage and breakage (see Burgess \& Gerloff 1981, 59-60 \& 99-103; Burgess \& Colquhoun 1988, 13-16). Several examples of spearhead from the United Kingdom and continental Europe also illustrate the conversion of objects in to new forms. For example, a possible spearhead or dagger from the lake-settlement Mörigen (Lake Biel, Switzerland) was evidently manufactured from a sword blade (Tarot 2000, no. 421), while numerous examples of Bronze Age looped spearhead in Britain show evidence of conversion to pegged spearheads or the retention of loop features in the LBA pegged type (Davis 2012). The conversion of swords into new weapons, or re-use of hilts/blades, and retention of archaic features in spearheads may represent the intentional extension of specific weapon biographies and the evocation of past social identities (cf. Davis 2012, 163; Kristiansen \& Larsson 2005, 231; Mödlinger 2011). While the manufacture of new weapons from old ones, to update the pieces to new styles or as the result of damage or wear, may indicate a clear concern with extending the social biography of specific items, the conversion/re-use of swords to/as swords does not involve a change of category or object concept.

It is somewhat self-evident that items which displayed properties similar to the desired form of the new object were selected for modification; the conversion of a sword blade into a spearhead would be relatively simple, while hollow ring jewellery would have been of sufficient dimensions and thickness to make a razor. On the other hand, to create a spearhead from an arm-ring through direct conversion would have been difficult.

While many arm- and leg-rings are found in a fragmentary state, for example $c$. 50 per cent of the Corcelettes-type and c. 45 per cent of Mörigen-type rings detailed by Pászthory (1985), it is clear that breakage of an object did not equate to the end of their use life. In addition to those objects that were converted into razors, several instances of repair to broken or cracked rings are observed (Table 1; Fig. 9). Small holes were drilled through either side of a damaged area and then secured with wire, allowing the object to continue its life and remain in use for social practices. It is not clear when damage to these items occurred - at the manufacturing stage 


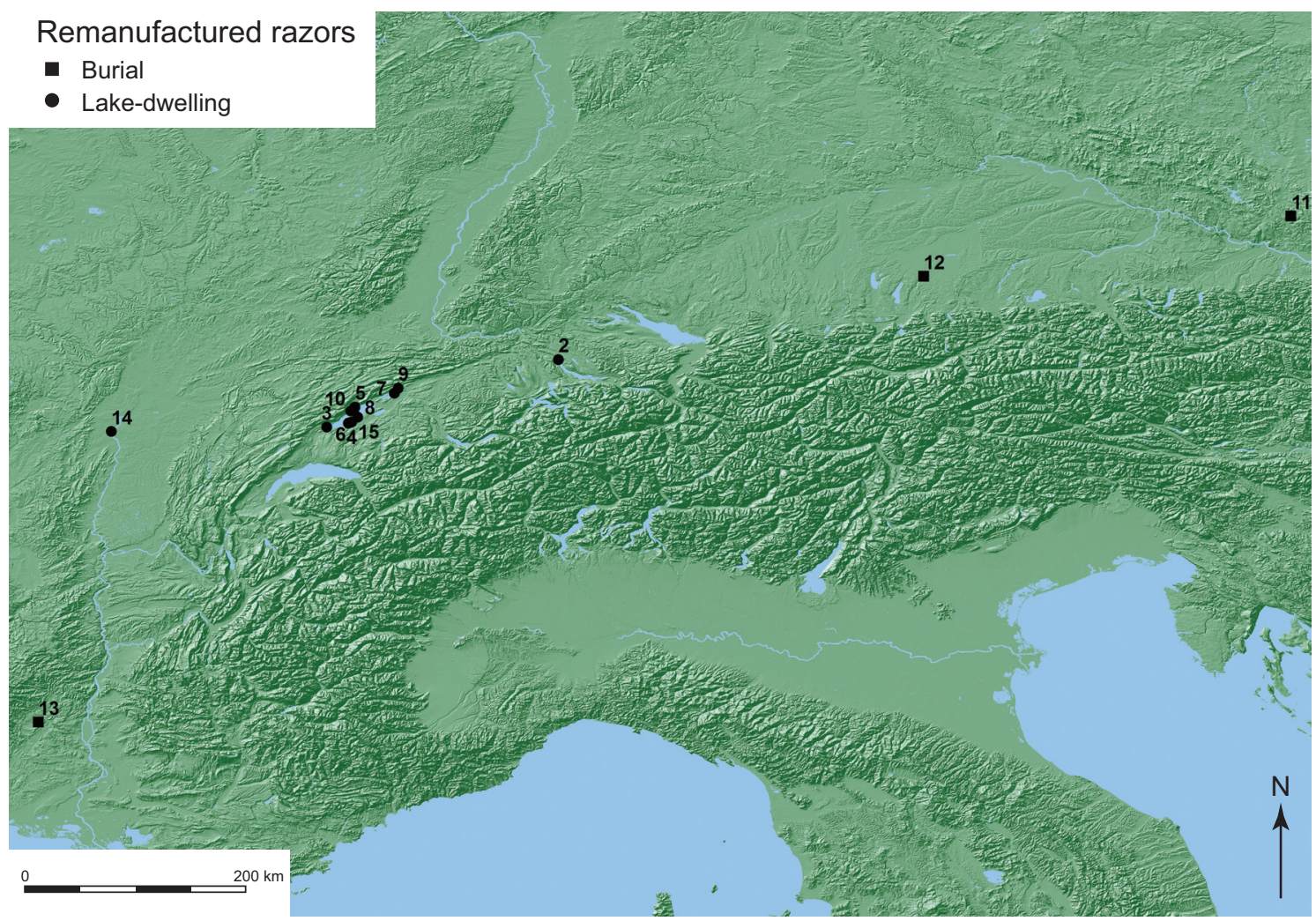

Figure 9. Distribution of razors of types remanufactured from arm-/leg-rings or other objects, repaired arm-/leg-rings, and partially molten ring jewellery. Numbers refer to Table 1. (Data from Jockenhövel 1971; 1980; Pászthory 1985.)

or during their use life. However, repair of these pieces may have required metalworkers, not only for their skills but also their equipment and materials. If such repairs were undertaken by metalworkers, then the question must be asked why the object was repaired instead of being melted and manufactured into a new one.

\section{Why convert objects?}

The vast majority of arm-/leg-rings and razors known from the northern Circum-Alpine region are from lake-settlement contexts. Outside of the lake-dwelling region some rings (of the predominant lake-dwelling types) are known from hoards, particularly in eastern France, and burials, in Germany and occasionally Switzerland. However, recovery from lake-settlement contexts does not mean that an object was casually discarded or lost in a settlement during its life. For instance, an intra-settlement hoard at Auvernier-Nord contained numerous examples of the Corcelettes-type ring (Fischer 2012; Pászthory 1985; Rychner 1979; 1987), demonstrating that meaningful and intentional deposition occurred within the lake- settlements. Other hoards within lake-settlements may not have been recognized at their time of excavation - especially sites 'recorded' in the nineteenth century (Fischer 2011; 2012; Menotti 2012, 3; Primas 1977, 53). Given their high frequency of occurrence, highly ornate decoration, and presence in hoards and burials, ring jewellery clearly performed a significant role in the social display of Late Bronze Age communities in the NCA and further afield. In contrast, razors are an extremely uncommon occurrence in burial and hoard contexts from the northern Circum-Alpine region: over 95 per cent of the examples recorded from Switzerland are single items from lake-dwelling contexts (from catalogue of Jockenhövel 1971). In addition, the proportion of decorated razors is quite low (c. 20 per cent), and when decoration does occur it follows no repetitive patterns or schemes which can be observed on other forms of material culture (e.g. ring jewellery and knives) (see Jockenhövel 1971). When compared to razors from the Nordic region (e.g. Kaul 1998; 2004), there is evidently a marked difference in the symbolism and importance associated with razors and shaving/grooming. Thus, through the conversion of 
ring jewellery into razors within the lake-dwelling communities of Switzerland highly socially charged objects were being transformed into, given their typical unstructured deposition and low decoration rates, objects which may have possessed relatively little social value and symbolism.

Explanations for such transformation can be categorized as either practical recycling of material, or social actions designed to continue the circulation of objects. Practical recycling of material would occur when objects were broken and, instead of wasting the fragmented bronze, they were converted into a required object - in these instances razors. However, as has been mentioned above, several instances of armand leg-rings with repairs are known from the NCA, indicating that ring jewellery was not necessarily discarded or reached the end of its biography when they became damaged (cf. Martin 2012). Modification into other objects may have offered a route to extend this biography even further, though how damaged/broken these objects must have become for consideration to be given to conversion of the item is unknown. Such conversion could have been undertaken by the owners of the broken object using improvised tools, or metal workers who would have possessed the equipment (chisels, hammers and anvils) and skills to complete the work. If the conversion was undertaken by 'specialized' metalworkers, why were the fragments not melted down to cast new objects? A significant amount of bronze would have been surplus after cutting a razor from a ring, or fragment thereof, which would most likely have been converted into other objects instead of simply being discarded. Yet, due to the low representation of ring-razor hybrids, evidently not all of the fragments were converted into razors.

Retention of objects and their continued circulation and use over extended periods of time could have been achieved through the conversion of one item into another, effectively creating 'heirlooms' from older objects. However, it is evident that the 'parent' ring jewellery and 'child' razor are roughly contemporary, although the typological chronology used to classify these objects does not carry the same dating resolution as many of the dendrochronologically dated lake-dwellings, and specific styles are identified only to $c$. 100-150 years, equating to several generations of potential owners. The retention of ancient objects in Late Bronze Age lake-dwelling communities has been demonstrated through a study of metalwork assemblages from around the lakes of western Switzerland (Fischer 2011; 2012). Although these objects only account for a minority of the assemblage, they are notable by their presence at Mörigen, Geneve-Eaux Vives and Auvernier-Nord.
The use of heirlooms as a method of generating social identities, identity retention and social legitimization has been discussed for societies inhabiting various areas of Europe (e.g. Caple 2010; Denison 2000; Lillios 1999; Woodward 2002), not only with regard to objects of material culture, but also human remains (Shapland \& Armit 2012). Interestingly, human remains, particularly skull fragments, have been recovered from several LBA lake-dwellings (Andrey 2006; Baumeister 2009; Menotti et al. in press), though their burial practices, with the exception of cemeteries at Lausanne (Moinat \& David-Elbiali 2003) and Le Boiron (Beeching 1977), remain largely unknown. Retention of objects, albeit transformed into new pieces, could have provided a link to the past and other members of communities. Converted objects deviate from the generally accepted biography of metalwork objects as detailed by Ottaway (2001) and Fontijn (2002) (Fig. 1), in that they do not enter the archaeological record (or re-melting process) at the appropriate stage; they are extracted from the system and re-circulated as a new object while retaining direct reference to their past biography (Fig. 10). The decoration, inherited from the parent ring jewellery, apparent on the arm-ring-razors clearly identifies them as being re-manufactured from sections of ring jewellery; no other metal artefacts from Switzerland relating to the Late Bronze Age have such rich decoration on their surface. This is readily apparent to archaeologists/researchers today, and would have been even more so to individuals living in the Late Bronze Age and viewing these objects during social practices. The decoration would have been relatively easy to remove, or at least subdue, through metalworking practices (e.g. grinding, polishing) if this had been desired, though evidently this was not the case. Whoever made these razors clearly intended that the decoration should be visible, apparent and identifiable on the surface.

Motivations for the incorporation and display of residual decoration may include the retention of items belonging to absent (e.g. through death or relocation) members of society. The use of personal jewellery, albeit in a new form, may have acted as a continuation of social presence and action; effectively a way of remembrance through mnemonic devices (cf. Caple 2010; Chapman 2000; Chapman \& Gaydarska 2007; Skeates 2010). Contrastingly, the physical destruction of an object, and continual sign and visibility of that destruction through its presence in another form, could have formed a sense of individual/personal or communal 'forgetting' - deliberately signifying that an object, and what that object represented, no longer exists (cf. Jones 
Figure 10. Expansion of the 'biographical' model of metalwork to account for the potential influence and effects of the extraction of material through processes of 'singularization'.

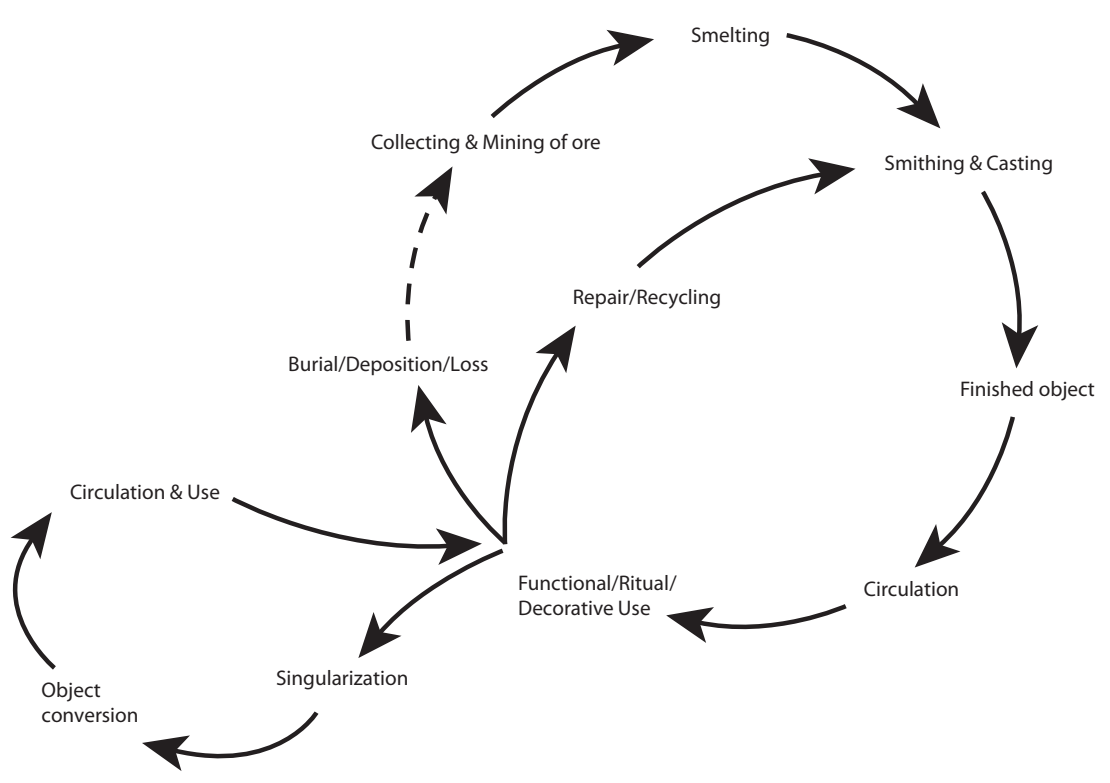

2007). Alternatively, the conversion of one object into another may have symbolized progression through various life-stages of a single individual, with the conversion occurring at socially significant stages. Owing to the low number of burials known that are related to lake-dwelling settlements and communities, gender associations are difficult to identify for the ring jewellery of the Late Bronze Age, but some ring fragments are recorded from the cremation of a 35- to 45-year-old male at Vidy-Chavannes (Kaenel \& Klausener 1990; Moinat \& David-Elbiali 2003). Moreover, outside of the region, ring jewellery is known from both male and female burials (e.g. Kubach-Richter 1981; Richter 1970), so conversion from ring to razor does not need to be considered a 'cross-gender' event.

If an interpretation following 'Occam's razor' (the principle of parsimony) is preferred, under which the simplest explanation is considered the best one, then the utilization of broken objects for conversion into new ones must be accepted. However, as has been detailed above, this practice seems unlikely given: a) the repairs seen on several armrings; b) the apparent abundance of undecorated bronze plate work in circulation during the LBA (indicated by the numbers of plain plate razors); c) the opportunity to re-melt and re-cast the object (e.g. Grandson-Corcelettes agglomerate); d) the coincidence needed for a razor to be required while having a broken ring available; and e) the fact that 'simple' or 'logical' actions are not always followed. Social factors should be considered as the driving influence for the choice to convert these objects, and not simply economy of material.

\section{'Ancestor cult' or the individualization of objects?}

Given the low occurrence of converted objects in the Late Bronze Age, these ring-razors should not be seen as a sign of 'ancestor cult 'or ancestor worship or widespread practices of heirloom creation. Such 'ancestor' practices and creation of heirloom objects would likely have revolved around objects with highly socially charged meanings, observable through their inclusion in such social actions as burials. The symbolic use of ancestral objects, relations and origins in the present through ritual actions, practices and locations has been considered as one of the key chiefly strategies of legitimization and control during the Bronze Age (Harding 2000, 74; Kristiansen \& Larsson 2005, 45). Such practices in the northern Circum-Alpine region may have utilized the arm-/leg-rings themselves; with highly ornate decoration and frequent internal markings (which may represent makers' marks, owners' marks, or illustrate the sequence in which rings should be combined: e.g. Hagl 2008, 38; Rychner-Faraggi 1993, 52), these objects would be easily identifiable. Although many rings shared similar schemes of decoration, subtle differences in the internal patterns may have made them identifiable as individual rings, linking them to specific individuals and merging their identities. While ring jewellery was occasionally included in burials (e.g. Le Boiron, Vidy-Chavannes), the high numbers of these objects known suggests that they were relatively abundant in society, making their use as elite ancestral legitimation devices somewhat limited. Furthermore, the individual identification of the rings may only be possible when the whole pattern is visible, not only a small section cut from the larger whole. Thus, second- 
ary object razors should not necessarily, in this situation, be seen as attempts to legitimize social status or practices over several generations.

Instead, it is suggested that these ring-razors provide an excellent example of 'singularized objects' (Kopytoff 1986, 73-7); objects which were given meaning by their owners, and which ties them closely to the object, but is not evident to other members of a community (Kopytoff 1986, 76). The removal of these rings from one sphere of valuation with well-defined social biographies from production to deposition, and insertion to another with a less clearly defined biography, created an extension to the biography of the first object. Deposition of these objects with extended biographies, and razors in general within the northern Circum-Alpine region, does not occur in burials or other structured depositions during the Late Bronze Age; their use as objects of social identity creation was apparently very limited. Thus, secondary ring-razors should be interpreted as mnemonic devices, as personal 'mementos' created from individualized objects, for use in either private or public grooming practices. While potential observers of these secondary razors would have easily recognized the original source of decoration adorning their surface (ring jewellery), due to the fragmentation of the motif it is doubtful that they would have recognized social associations of the object if they were not aware of the actual act of conversion.

\section{Conclusion}

Studies of Late Bronze Age metalworking practices often emphasize the role of recycling old, broken and surplus metal objects through an effectively invisible process of 'primary recycling': re-melting and re-casting (Fontijn 2002; Ottaway 2001). Frequent findings of so-called 'founders hoards' provide support for such interpretations in the form of collections of material stockpiled in advance of recycling (Harding 2000, 354; but compare Bradley 2005, 148-57), and an agglomerate mass of half-molten objects from the lake-settlement Grandson-Corcelettes (Wyss 1967) provides a direct indication of such activities in the northern Circum-Alpine region. However, in the light of archaeometallurgical studies (Rychner \& Kläntschi 1995), how widespread such primary recycling was in the northern Circum-Alpine region must be questioned. Practices of 'secondary manufacture', or the direct conversion of one object into another are evidenced in the lake-dwellings of Switzerland through bronze plate razors bearing decoration typical of various regional types of ring jewellery.

Recycling practices utilizing direct conversion, rather than total destruction through re-melting, permit an object's biography to be extended through time, beyond the use period of one object into a second, while visibly retaining the biographical associations contained within the primary object. Such extended biographies have elsewhere been considered as practices of heirloom creation and the presencing of ancestors in the present (e.g. Lillios 1999; Woodward 2002). However, the low occurrence of these converted arm-ring-razors and their rough temporal contemporaneity suggests that they were not part of widespread social practices intended to create ancestral links, but rather that they were 'individualized' objects selected for retention by their owners. In this manner, the razors could have been utilized as personal mnemonic devices to recall other places, times, individuals or events. In addition to extending the biography of ring jewellery into another regime, an effective social devaluation of the object occurred: from the richly decorated arm-/leg-rings, which were often included in burials as identity or status-generating and signifying objects, to razors which were typically undecorated and seldom included in burial assemblages within the northern Circum-Alpine region.

While secondary recycling/conversion of objects may be more visible than the primary recycling/melting of objects, it is still dependent upon recognizable features being present on the objects. The examples of razors cut from arm-rings are only identifiable as being so because of the decoration visible on their surface. Had this decoration been removed during the conversion process, through hammering or grinding, then it would have been impossible to identify the source of the metal plate work. Many of the Late Bronze Age single-sided razors from the northern Circum-Alpine region were cut from bronze plate work, though the source of this plate remains unknown because the razors do not show any typological features of decoration present on other objects. The occurrence of 'relic' objects in lake-settlements of the Late Bronze Age in western Switzerland provides indications that objects were being curated over extended periods of time within this region (Fischer 2011; 2012), and by the same societies that were creating secondary manufactured objects, as the individualization of specific objects by community members to place past identities in the present.

\section{Acknowledgements}

I would like to thank Francesco Menotti for his suggestions and corrections during the preparation of this paper; any shortcomings within the text are entirely my own. The comments and suggestions of the two anonymous external reviewers were gratefully received, and their suggestions 
have helped to significantly improve the paper. I would also like to express my gratitude to the staff of the Swiss National Museum (Zurich) and the Historical Museum of Basel for their assistance in providing direct access to primary materials for photography. This paper was inspired by research for my PhD at the University of Basel, for which I was financially supported by the Swiss National Science Foundation (SNF), project number SNF 123336. Finally, I would like to thank the staff and editors of the Cambridge Archaeological Journal for all of their assistance in preparing this paper.

Benjamin Jennings
IPNA - University of Basel
Spalenring 145
CH-4055 Basel
Switzerland
Email: benjamin.jennings@unibas.ch

\section{References}

Andrey, S., 2006. Les ossements humains épars des stations littorales de la région des Trois-Lacs. Cahiers d'Archéologie Fribourgeoise 8, 146-61.

Appadurai, A., 1986. Introduction: commodities and the politics of value, in The Social Life of Things: Commodities in Cultural Perspective, ed. A. Appadurai. Cambridge: Cambridge University Press, 3-63.

Baumeister, R. (ed.), 2009. Mord im Moor? Bad Schussenried: Federsee Museum Bad Buchau.

Beeching, A., 1977. Le Boiron: une nécropole du Bronze Final près de Morges (Vaud, Suisse). Lausanne: Musée d'archéologie et d'histoire.

Boisaubert, J.-L., D. Bugnon \& M. Mauvilly, 2008. Archéologie et Autoroute A1, destins Croisés: 25 années de fouilles en terres Fribourgeoises, premier bilan (1975-2000). Fribourg: Service archéologique de l'État de Fribourg.

Bradley, R., 1988. Hoarding, recycling and the consumption of prehistoric metalwork: technological change in western Europe. World Archaeology 20(2), 249-60.

Bradley, R., 2005. Ritual and Domestic Life in Prehistoric Europe. London: Routledge.

Brück, J., 2006. Fragmentation, personhood and the social construction of technology in Middle and Late Bronze Age Britain. Cambridge Archaeological Journal 16(3), 297-315.

Burgess, C. \& I. Colquhoun, 1988. The Swords of Britain. Munich: C.H. Beck.

Burgess, C. \& S. Gerloff, 1981. The Dirks and Rapiers of Great Britain and Ireland. Munich: C.H. Beck.

Caple, C., 2010. Ancestor artefacts - ancestor materials. Oxford Journal of Archaeology 29(3), 305-18.

Chapman, J., 2000. Fragmentation in Archaeology: People, Places and Broken Objects in the Prehistory of South Eastern Europe. London: Routledge.

Chapman, J. \& B. Gaydarska, 2007. Parts and Wholes: Fragmentation in Prehistoric Context. Oxford: Oxbow Books.

Davis, R., 2012. The Early and Middle Bronze Age Spearheads of Britain. Stuttgart: Franz Steiner.
Denison, S., 2000. News: The man, the grave and the antique arrow: Bronze Age warrior found clutching heirloom. British Archaeology, 51. http://www.archaeologyuk. org/ba/ba51/ba51news.html. [Accessed 19 Feb 2014.]

Fischer, V., 2011. The deposition of bronzes at Swiss lakeshore settlements: new investigations. Antiquity 85(330), 1298-311.

Fischer, V., 2012. Les Bronzes en Contexte Palafittique sur les Rives du Léman et des Trois-Lacs (Suisse occidentale). Lausanne: Musée cantonal d'archéologie et d'histoire.

Fontijn, D.R., 2002. Sacrificial Landscapes: Cultural Biographies of Persons, Objects and 'Natural' Places in the Bronze Age of the Southern Netherlands, c. 2300-600 B.C. Leiden: University of Leiden.

Gosden, C. \& Y. Marshall, 1999. The cultural biography of objects. World Archaeology 31(2), 169-78.

Hagl, M., 2008. Ein urnenfelderzeitlicher Depotfund vom Bullenheimer Berg in Franken (Hort F). Munich: Verlag C.H. Beck.

Harding, A.F., 2000. European Societies in the Bronze Age. Cambridge: Cambridge University Press.

Heierli, J., 1886. Der Pfahlbau Wollishofen. Mitteilungen der antiquarischen Gesellschaft in Zürich 22(1), 1-32.

Hüttel, H.-G., 1981. Bronzezeitliche Trensen in Mittel- und Osteuropa: grundzüge ihrer Entwicklung. Munich: C.H. Beck.

Jockenhövel, A., 1971. Die Rasiermesser in Mitteleuropa (Süddeutschland, Tschechoslowakei, Österreich, Schweiz). Munich: C.H. Beck.

Jockenhövel, A., 1980. Die Rasiermesser in Westeuropa (Westdeutschland, Niederlande, Belgien, Luxemburg, Frankreich, Grossbritannien und Irland). Munich: C.H. Beck.

Jones, A., 2007. Memory and Material Culture, Cambridge: Cambridge University Press.

Kaenel, G. \& M. Klausener, 1990. Quelques tombes à incinération du Bronze final (Xe siècle av. J.-C.) à Vidy (Lausanne VD). Jahrbuch der Schweizerischen Gesellschaft für Ur- und Frühgeschichte 73, 51-82.

Kaul, F., 1998. Ships on Bronzes: a Study in Bronze Age Religion and Iconography. Copenhagen: National Museum of Denmark.

Kaul, F., 2004. Social and religious perceptions of the ship in Bronze Age northern Europe, in The Dover Bronze Age Boat in Context: Society and Water Transport in Prehistoric Europe, ed. P. Clark. Oxford: Oxbow Books, 122-37.

Kopytoff, I., 1986. The cultural biography of things: commoditization as process, in The Social Life of Things: Commodities in Cultural Perspective, ed. A. Appadurai. Cambridge: Cambridge University Press, 64-91.

Krämer, W., 1985. Die Vollgriffschwerter in Österreich und der Schweiz. Munich: C.H. Beck.

Kristiansen, K. \& T.B. Larsson, 2005. The Rise of Bronze Age Society: Travels, Transmissions, and Transformations. Cambridge: Cambridge University Press.

Kubach-Richter, I., 1981. Der bronzezeitliche Arm- und Beinschmuck zwischen nördlichem Oberrhein und mittlerer Mosel. Unpublished PhD dissertation, University of Frankfurt am Main.

Lillios, K.T., 1999. Objects of memory: the ethnography and archaeology of heirlooms. Journal of Archaeological 
Method and Theory 6(3), 235-62.

Martin, T., 2012. Riveting biographies: the theoretical implications of early Anglo-Saxon brooch repair, customisation and use-adaptation, in Make-do and Mend: Archaeologies of Compromise, Repair and Reuse, eds. B. Jervis \& A. Kyle. (British Archaeological Reports, International Series 2408.) Oxford: Archaeopress, 53-65.

Menotti, F., 2012. Wetland Archaeology and Beyond: Theory and Practice. Oxford: Oxford University Press.

Menotti, F., B. Jennings \& H. Gollnisch-Moos, in press. 'Gifts for the Gods': lake-dwellers' macabre remedies against floods in central Europe Bronze Age. Antiquity.

Mödlinger, M., 2011. Herstellung und Verwendung bronzezeitlicher Schwerter Mitteleuropas: eine vertiefende Studie zur mittelbronze- und urnenfelderzeitlichen Bewaffnung und Sozialstruktur. Bonn: Rudolf Habelt.

Moinat, P. \& M. David-Elbiali, 2003. Défunts, bûchers et céramiques: la nécropole de Lausanne-Vidy (VD) et les pratiques funéraires sur le Plateau Suisse du XIe au VIIIe s.av.J.-C. Lausanne: Cahiers d'archéologie romande.

Northover, P., 2009. Analysis and metallography of copper alloy metalwork, in Das spätbronze- und früheisenzeitliche Gräberfeld von Bischofshofen-Pestfriedhof, eds. A. Lippert \& P. Stadler. Bonn: Habelt, 351-84.

Ottaway, B.S., 2001. Innovation, production and specialization in early prehistoric copper metallurgy. European Journal of Archaeology 4(1), 87-112.

Ottaway, B.S. \& B. Roberts, 2008. The emergence of metalworking, in Prehistoric Europe: Theory and Practice, ed. A. Jones. Chichester: Wiley-Blackwell, 193-225.

Pászthory, K., 1985. Der Bronzezeitliche Arm-und Beinschmuck in der Schweiz. Munich: C.H. Beck.

Patay, P. \& É.F. Petres, 1990. Die Bronzegefässe in Ungarn. Munich: C.H. Beck.

Primas, M., 1977. Beobachtungen zu den spätbronzezeitlichen Siedlungs- und Depotfunden der Schweiz, in Festschrift Walter Drack zu Seinem 60. Geburtstag, eds. K. Stüber \& A. Zürcher. Zürich: Th. Gut \& Co., 44-55.

Primas, M., 1986. Die Sicheln in Mitteleuropa I (Österreich, Schweiz, Süddeutschland). Munich: C.H. Beck.

Quillfeldt, I. von, 1995. Die Vollgriffschwerter in Süddeutschland. Stuttgart: Franz Steiner.

Richter, I., 1970. Der Arm- und Beinschmuck der Bronze- und Urnefelderzeit in Hessen und Rheinhessen. Munich: C.H. Beck.

Roberts, B., 2009. Production networks and consumer choice in the earliest metal of western Europe. Journal of World Prehistory 22(4), 461-81.

Rychner, V., 1979. L'âge du Bronze Final à Auvernier (Lac de Neuchâtel, Suisse): typologie et chronologie des anciennes collections conservées en Suisse. Lausanne: Bibliothèque historique vaudoise.

Rychner, V., 1984. La matière première des bronziers lacustres. Archäologie der Schweiz 7(2), 73-8.

Rychner, V., 1987. Auvernier 1968-1975, le mobilier métallique du Bronze Final: formes et techniques. Lausanne: Biblio- thèque historique vaudoise.

Rychner, V., 1998. Chronologie, in Bronzezeit: Die Schweiz vom Paläolithikum bis zum frühen Mittelalter, eds. S. Hochuli, U. Niffeler \& V. Rychner. Basel: Verlag Schweizerische Gesellschaft für Ur- und Frühgeschichte, 13-19.

Rychner, V. \& N. Kläntschi, 1995. Arsenic, nickel et antimoine: une approche de la métallurgie du Bronze Moyen et Final en Suisse par l'analyse spectrométrique. Lausanne: Cahiers d'archéologie romande.

Rychner-Faraggi, A.-M., 1993. Hauterive-Champréveyres, vol. 9: Métal et parure au Bronze Final. Neuchâtel: Musée cantonal d'archéologie.

Schauer, P., 1971. Die Schwerter in Süddeutschland, Oesterreich und der Schweiz I: (Griffplatten-, Griffangel- und Griffzungenschwerter). Munich: C.H. Beck.

Seifert, M., 1997. Die Funde der Grabungen 1952-54. Zug: Kantonales Museum für Urgeschichte Zug.

Shapland, F. \& I. Armit, 2012. The useful dead: bodies as objects in Iron Age and Norse Atlantic Scotland. European Journal of Archaeology 15(1), 98-116.

Skeates, R., 2010. The art of memory: personal ornaments in Copper Age south-east Italy, in Material Mnemonics: Everyday Memory in Prehistoric Europe, eds. K.T. Lillios \& V. Tsamis. Oxford: Oxbow Books, 73-84.

Sprockhoff, E., 1966. Ein Geschenk aus dem Norden, in Helvetia Antiqua: Festschrift Emil Vogt, eds. R. Degen, W. Drack \& R. Wyss. (Beiträge zur Prähistorie und Archäologie der Schweiz.) Zurich: Conzett und Huber, 101-10.

Tarot, J., 2000. Die bronzezeitlichen Lanzenspitzen der Schweiz: unter Einbeziehung von Liechtenstein und Vorarlberg. Bonn: Habelt.

Thrane, H., 1975. Europaeiske forbindelser: bidrag til studiet af fremmede forbindelser $i$ Danmarks Yngre Broncealder (periode $I V-V$ ). Copenhagen: National Museum of Denmark.

Tylecote, R.F., 1992. A History of Metallurgy. London: Institute of Materials.

Woodward, A., 2002. Beads and beakers: heirlooms and relics in the British Early Bronze Age. Antiquity 76(294), 1040-47.

Wyss, R., 1967. Bronzezeitliche gusstechnik. (Aus dem Schweizerischen Landesmuseum 19.) Bern: Paul Haupt.

Young, S.M.M., A.M. Pollard, P. Budd \& R.A. Ixer, 1999. Metals in Antiquity. (British Archaeological Reports, International Series 792.) Oxford: Archaeopress.

\section{Author biography}

Benjamin Jennings is a post-doctoral researcher at the Institute for Prehistoric and Archaeological Sciences at the University of Basel. His interests include European Late Bronze Age wetland settlements, long-distance exchange patterns, use of material culture, and maritime archaeology. 